\title{
Peningkatan Kualitas Hasil Belajar Pendidikan Kewarganegaraan di Sekolah Dasar Kelas Tinggi dengan Menggunakan Strategi Pembelajaran Aktif Tipe Crossword Puzzle
}

\author{
Heri Hidayat ${ }^{1}$, Heny Mulyani ${ }^{2}$, Kiki Karlina ${ }^{3}$, Luthika Tsalitsa Faqih ${ }^{4}$, dan Nitia Andi Narini ${ }^{{ }^{*}}$ \\ 1,2,3,4,5Pendidikan Guru Madrasah Ibtidaiyah Universitas Islam Negeri Sunan Gunung Djati \\ Bandung \\ E-mail: andinarini.nitia@gmail.com
}

\begin{abstract}
Abstrak
Proses pembelajaran yang menggunakan model, strategi, dan media pembelajaran yang kurang inovatif dan menarik mengakibatkan minat belajar siswa menjadi rendah. Selain itu, siswa kurang berpartisipasi aktif dalam pembelajaran sehingga mengakibatkan pembelajaran kurang bermakna bagi siswa. Pembelajaran yang berlangsung masih berpusat pada guru. Penelitian ini berjudul Peningkatan Kualitas Hasil Belajar Pendidikan Kewarganegaraan di Sekolah Dasar Kelas Tinggi dengan Menggunakan Strategi Pembelajaran Aktif Tipe crossword puzzle. Adapun permasalahan dalam penelitian ini adalah apakah ada peningkatan kualitas hasil belajar siswa dalam mata pelajaran Pendidikan Kewarganegaraan di sekolah dasar kelas tinggi dengan menggunakan strategi pembelajaran aktif tipe crossword puzzle. Tujuan penelitian ini untuk mendapakan gambaran objektif peningkatan hasil belajar Pendidikan Kewarganegaraan dengan menggunakan strategi pembelajaran aktif tipe crossword puzzle. Penelitian ini merupakan penelitian dengan menggunakan metode kajian pustaka. Peneliti mengkaji dari beberapa penelitian yang bersumber dari artikel lain. Dari hasil penelitian menunjukkan bahwa penerapan strategi pembelajaran aktif tipe crossword puzzle menjadikan pembelajaran lebih menyenangkan dan siswa mudah memahami materi pembelajaran.
\end{abstract}

Kata kunci: kualitas hasil belajar, pkn, crossword puzzle.

\section{PENDAHULUAN}

Sekolah merupakan lembaga pendidikan yang memiliki peran penting dalam terselenggaranya proses pembelajaran. Pendidikan merupakan upaya menghadapkan manusia (siswa) pada realita yang terus saja berubah saat ini,sehingga sangat diharapkan perannya untuk mampu mengikuti arus zaman bukan berarti untuk mengikis kemanusiaan melainkan untuk menemukan kondisi air kehidupan yang memungkinkan jiwa raga bangsa berenang dengan indah. (Soyomukti: 2008:43).

Tujuan pendidikan nasional adalah mengembangkan kemampuan dan membentuk watak serta peradaban bangsa yang bermartabat dalam rangka mencerdaskan kehidupan bangsa, bertujuan mengembangkan potensi siswa agar menjadi manusia yang beriman dan bertaqwa kepada Tuhan Yang Maha Esa, berakhlak mulia, sehat, berilmu, cakap, kreatif, dan mandiri dan menjadi warga Negara yang demokratis serta bertanggung jawab. Guru merupakan ujung tombak dunia pendidikan yang memiliki peran penting dalam melaksanakan kegiatan belajar mengajar. Melalui guru di sekolah diharapkan mampu menghasilkan siswa yang memiliki kompetensi tinggi dan siap menghadapi tantangan hidup yang semakin berat dengan penuh keyakinan dan percaya diri yang tinggi, Marno (2008:49).

Dalam proses belajar mengajar guru secara sadar melaksanakan strategi pembelajaran yaitu mendesain bagaimana proses pelaksanaan sampai bentuk evaluasi yang akan dilakukan untuk mencapai tujuan pembelajaran. Pada kenyataannya, proses pembelajaran saat ini cenderung masih 
berpusat pada guru dengan bercerita atau berceramah, siswa kurang terlibat secara aktif dalam proses pembelajaran, karena peran guru sangat dominan sebagai satu-satunya sumber belajar (Kumalasari, 2018)

Di dalam kegiatan belajar mengajar, strategi pembelajaran digunakan untuk menciptakan suasana pembelajaran yang aktif. Pembelajaran aktif merupakan sebuah pendekatan pembelajaran yang lebih banyak melibatkan aktivitas siswa dalam mengakses berbagai informasi dan pengetahuan untuk dibahas dan dikaji dalam pembelajaran di kelas sehingga siswa mendapatkan banyak pengalaman untuk meningkatkan kemampuan dan pengetahuannya (Zainul, 2012:81).

Guru memiliki peranan yang sangat penting maka seorang guru hendaknya memiliki strategi belajar yang dapat membuat siswa belajar secara aktif efisien, efektif serta tidak membuat siswa merasa jenuh dalam proses belajar mengajar agar tercapainya tujuan yang diharapkan. Diantara strategi-strategi pembelajaran aktif, salah satu strategi yang lebih memungkinkan keterlibatan siswa untuk lebih aktif dalam kegiatan pembelajaran adalah strategi crossword puzzle (Teka-Teki Silang).

Strategi pembelajaran crossword puzzle merupakan permainan teka-teki yang digunakan sebagai strategi pembelajaran menyenangkan, tanpa menghilangkan esensi belajar yang sedang berlangsung bahkan strategi ini dapat melibatkan partisipasi peserta didik secara aktif sejak awal (Zaini, 2008:71). Selain itu, strategi pembelajaran crossword puzzle adalah strategi pembelajaran untuk meninjau ulang materi-materi yang sudah disampaikan. Sehingga peserta didik mampu mencapai tujuan pembelajaran baik aspek kognitif, afektif, maupun psikomotorik.

Langkah-langkah strategi pembelajaran crossword puzzle adalah tulislah kata-kata kunci, terminologi, atau nama-nama yang berhubungan dengan materi yang anda berikan (seperti dalam teka-teki silang), membuat pertanyaan-pertanyaan yang jawabannya adalah kata-kata yang telah dibuat. Bagikan teka-teki ini kepada peserta didik dapat secara individu atau kelompok, batasi waktu pengerjaan, memberikan hadiah kepada kelompok atau individu yang mengerjakan paling cepat dan benar (Zaini, 2008:71).

Pendidikan Kewarganegaraan dapat diartikan sebagai wahana untuk mengembangkan dan melestarikan nilai luhur dan moral yang berakar pada budaya bangsa Indonesia yang diharapkan dapat diwujudkan dalam perilaku kehidupan sehari-hari siswa sebagai individu dan anggota masyarakat dalam kehidupan berbangsa dan bernegara.

Pendidikan Kewarganegaraan (Citizenship) merupakan mata pelajaran yang memfokuskan pada pembentukkan diri yang beragam dari segi agama sosio-kultural, bahasa, usia dan suku bangsa untuk menjadi warga Negara Indonesia yang cerdas, terampil, dan berkarakter yang dilandasi oleh Pancasila dan UUD 1945 (Winataputra, 1999:8).

Penerapan strategi pembelajaran crossword puzzle dalam pembelajaran PKn guru menyiapkan skenario pembelajaran, menyampaikan tujuan pembelajaran, menyampaikan materi pembelajaran meminta siswa secara berkelompok atau individu menyelesaikan soal teka-teki, membahas soal tekateki yang telah dikerjakan, memberikan hadiah kepada kelompok atau individu yang mengerjakan dengan cepat dan benar, memberikan kesimpulan secara umum bersama-sama siswa.

Tujuan penelitian di atas, maka tujuan penelitian untuk mendapatkan gambaran obyektif dan spesifik tentang peningkatan kualitas hasil belajar PKn di sekolah dasar siswa kelas tinggi dengan menggunakan strategi pembelajaran aktif tipe crossword puzzle.

\section{METODE/EKSPERIMEN}

Penelitian ini merupakan penelitian kajian kepustakaan yang menjadi salah satu pendekatan ilmiah yang digunakan untuk menganalisis isu-isu metode pembelajaran, yaitu metode pembelajaran crossword puzzle yang diterapkan dalam kelas. Untuk mengkaji masalah tersebut peneliti menelaah berbagai pustaka seperti jurnal atau untuk memahami lebih dalam mengenai bagaimana teknik pembelajaran tipe aktif crossword puzzle. Setelah peneliti menelaah berbagai pustaka, peneliti akan lebih mudah untuk memahami teknik pembelajaran tipe crossword puzzle.

Proses pelaksanaan tipe aktif crossword puzzle, para siswa dikelas dibagi menjadi beberapa 
kelompok yang terdiri dari 4-5 orang yang memiliki kemampuan, ras, suku, agama dan jenis kelamin yang berbeda. Guru memberikan suatu pembelajaran kepada setiap kelompok dan para siswa memastikan anggota kelompoknya dapat memahami dan menguasai bahan ajar melalui Tanya-jawab atau diskusi. Setelah itu guru melakukan evaluasi dengan cara memberikan kuis secara perorangan tentang materi tersebut. Kemudian guru memberikan apresiasi kepada setiap kelompok yang meraih nilai rata-rata tinggi.

\section{HASIL DAN PEMBAHASAN}

Hasil

Penerapan strategi pembelajaran aktif tipe crossword puzzle untuk meningkatkan hasil belajar PKn menurut Aisyah (2014). Siswa kelas V di MIN Kolomayan Wonodadi tahun ajaran 2013/2014 dari hasil penelitian disimpulkan baik pada taraf signifikan. Dari analisis data menggunakan tes dapat disimpulkan terdapat perbedaan hasil belajar peserta didik pada mata pelajaran PPKn sebelum dan setelah penggunaan metode strategi crossword puzzle. Berdasarkan hasil analisis tersebut juga dapat disimpulkan bahwa terdapat pengaruh penggunaan strategi crossword puzzle pada hasil belajar pada mata pelajaran PPKn siswa kelas V di MIN Kolomayan Wonodadi tahun ajaran 2013/2014.

Pengaruh penerapan strategi pembelajaran aktif tipe crossword puzzle (teka-teki silang) menurut Khasanah (2014), terhadap hasil belajar pada tema indahnya kebersamaan, sub tema keberagaman budaya bangsaku, pembelajaran ke-1 siswa kelas IV SDN IV Metro Timur. Berdasarkan hasil analisis diketahui bahwa strategi pembelajaran aktif tipe teka-teki silang berpengaruh terhadap hasil belajar siswa. Hal ini berdasarkan hasil perhitungan uji lerata postest diketahui bahwa nilai lerata postest siswa kelas IV B yaitu 77,50 lebih besar dibandingkan kelas IV C yaitu 71,79.Selisih antar dua kelompok kelas yaitu 5,71.

Menurut Aniza (2018), Hasil penelitian menunjukkan bahwa nilai hasil belajar dan keaktifan peserta didik mengalami peningkatan. Hasil dapat dilihat dari ketuntasan belajar peserta didik pada siklus I dengan rata-rata 73,1 . Pada siklus II, rata-rata ketuntasan belajar peserta didik meningkat menjadi 83,3. Dari hasil observasi, nilai keaktifan peserta didik pada siklus I mencapai rata-rata 63,3 dengan kategori aktif. Pada siklus II, rata-rata keaktifan peserta didik meningkat menjadi 81,7 dengan kategori sangat aktif. Berdasarkan hasil penelitian tersebut dapat disimpulkan bahwa pembelajaran dengan menggunakan strategi pembelajaran crossword puzzle dapat meningkatkan hasil belajar peserta didik pada subtema Peristiwa Kebangsaan Masa Penjajahan di kelas V SD Negeri 91 Palembang.

\section{Pembahasan}

Menurut Zaki (2016) dalam Undang-Undang Sistem Pendidikan Nasional No.20 Tahun 2003 menyatakan pembelajaran adalah "proses interaksi peserta didik dengan pendidik dan sumber belajar pada suatu lingkungan belajar." Pembelajaran sebagai proses pembelajaran yang dibangun oleh guru untuk mengembangkan kreatifitas berfikir yang dapat meningkatkan kemampuan berfikir siswa, serta dapat meningkatkan kemampuan mengkontruksikan pengetahuan baru sebagai upaya meningkatkan penguasaan yang baik terhadap materi pelajaran.

Pendidikan kewarganegaraan (citizenship) merupakan mata pelajaran yang memfokuskan pada pembentukan diri yang breragam dari segi agama, sosio cultural, bahasa, usia dan suku bangsa untuk menjadi warga Negara yang cerdas, terampil, dan berkarakter yang diamanatkan oleh pancasila dan undang-undang dasar 1945.

Pembelajaran PKn di sekolah dasar dimaksudkan sebagai suatu proses pembelajaran dalam rangka membantu siswa agar dapat belajar dengan baik dan membentuk manusia Indonesia seutuhnya. Pembentukan karakter bangsa yang diharapkan mengarah kepada terciptanya suatu masyarakat yang menempatkan demokrasi dalam kehidupan berbangsa dan bernegara yang berlandaskan pada Pancasila, UUD, dan norma-norma yang berlaku di masyarakat. Tujuan pembelajaran PKn di sekolah dasar adalah untuk menjadikan warga negara yang baik, yaitu warga 
negara yang tahu, mau dan sadar akan hak dan kewajibannya. Dengan demikian diharapkan kelak dapat menjadi bangsa yang terampil dan cerdas, yang bersikap baik sehingga mampu mengikuti kemajuan teknologi modern.

Perubahan seseorang yang asalnya tidak tahu menjadi tahu merupakan hasil dari proses belajar. Perubahan yang terjadi melalui belajar tidak hanya mencakup pengetahuan, tetapi juga keterampilan untuk hidup (lifes kill) bermasyarakat meliputi keterampilan berpikir (memcahkan masalah), keterampilan sosial, dan yang tidak kalah pentingnya adalah nilai dan sikap. Akan tetapi tidak semua perubahan yang terjadi dalam diri seseorang merupakan hasil dari proses belajar. Yang harus digarisbawahi bahwa perubahan hasil belajar diperoleh karena individu yang bersangkutan berusaha untuk belajar.

Susanto (2013: 4) mengemukakan bahwa belajar merupakan suatu aktivitas yang dilakukan seseorang secara sadar untuk memperoleh suatu konsep, pengetahuan, atau pengetahuan baru sehingga memungkinkan seseorang terjadinya perubahan perilaku yang relatif tetap baik dalam berpikir, merasa, maupun dalam bertindak. Kasmadi dan Sunariah (2014: 29) mendefinisikan bahwa belajar adalah salah satu usaha yang disengaja, bertujuan, terkendali, agar orang lain belajar atau terjadi perubahan yang relatif menetap pada diri seseorang.

Berdasarkan pendapat para ahli peneliti menyimpulkan bahwa belajar adalah aktivitas atau usaha secara sadar yang disengaja, memiliki tujuan, dan terkendali agar terjadinya proses belajar serta untuk memperoleh suatu konsep, pengetahuan, maupun wawasan baru seseorang sehingga dapat memberikan perubahan yang positif pada diri seseorang. Dengan belajar juga sesorang dapat berpikir, bertindak, dan merasa dengan baik berdasarkan pengetahuan maupun pengalamannya.

Hasil belajar merupakan hasil akhir dari pembelajaran, karena hasil belajar menggambarkan keberhasilan atau kegagalan dalam proses pembelajaran. Susanto (2013: 5) mengemukakan bahwa hasil belajar adalah perubahan-perubahan yang terjadi pada diri siswa, baik yang menyangkut aspek kognitif, afektif, dan psikomotorik sebagai hasil dari kegiatan belajar. Kasmadi dan Sunariah (2014: 44) hasil belajar secara normatif merupakan hasil penilaian terhadap kegiatan pembelajaran sebagai tolak ukur tingkat keberhasilan siswa dalam memahami pembelajaran yang dinyatakan dengan nilai berupa huruf atau angka.

Berdasarkan pendapat para ahli, peneliti menyimpulkan bahwa hasil belajar adalah hasil akhir dari pembelajaran yang menggambarkan berhasil atau tidaknya proses pembelajaran, yang dapat membuat adanya perubahan-perubahan yang terjadi pada diri siswa. Hasil belajar ini menyangkut bebrapa aspek yaitu aspek kognitif, afektif dan psikomotorik. Hasil belajar juga menjadi tolak ukur tingkat keberhasilan siswa dalam memahami pembelajaran yang dinyatakan dalam penilaian kualitatif dan kuantitatif.

Berdasarkan kurikulum 2006, hasil belajar berkaitan dengan kompetensi. Kompetensi merupakan pengetahuan, keterampilan, dan nila-nilai dasar yang di refleksikan dalam kebiasaan berfkir dan bertindak. Menurut Mulyasa (2005) hasil belajar merupakan prestasi belajar siswa secara keseluruhan dan menjadi indikator kompetensi yang harus dikuasai siswa perlu dinyatakan sedemikian rupa agar dapat dinilai sebagai wujud hasil belajar siswa yang mengacu pada pengalaman langsung.

Menurut Sudjana (2001) menyatakan bahwa hasil belajar yang dicapai siswa dipengaruhi oleh dua faktor utama yaitu faktor dalam diri siswa meliputi : (1) kemampuan yang dimilikinya, (2) motivasi siswa, (3) minat dan perhatian, (4) sikap dan kebiasaan belajar, (5) faktor fisik dan psikis. Sedangkan faktor dari luar diri siswa meliputi : (1) kualitas pengajaran,(2) besarnya kelas dan suasana, (3) fasilitas dan sumber belajar .

Oktavia dalam Sudjana (2004) menyatakan bahwa ada tiga ranah penilaian hasil belajar yakni ranah kognitif, meliputi: pengetahuan, pemahaman, aplikasi, analisis, sintesis, dan evaluasi. Ranah afektif meliputi: penermaan, jawaban atau reaksi, penilaian, dan organisasi. Selanjutnya ranah psikomotor merupakan keterampilan dan kemauan dalam bertindak. Dari ketiga ranah tersebut yang banyak digunakan oleh guru disekolah adaah ranah kognitif karena berkaitan dengan kemampuan 
para siswa dalam menguasai isi bahan pengajaran.

Kata strategi berasal dari kata yunani kuno strategis yang berarti merencanakan (to plan). menurut Kamus Besar Bahasa Indonesia strategi berarti rencana yang cermat mengenai kegiatan untuk mencapai sasaran khusus. Sedangkan pembelajaran adalah upaya agar siswa belajar. Dan dalam pembelajaran itu dibutuhkan suatu strategi pembelajaran yang merupakan suatu upaya agar tujuan pembelajaran dapat tercapai.

Menurut Dewi (2017) mengungkapkan dalam bukunya bahwa strategi pembelajaran merupakan suatu rencana pembelajaran yang dirancang sesuai dengan tuntutan kurikulum dengan memilih pendekatan metode materi media dan sarana pendukung pembelajaran yang relevan dan merupakan dalam memfasilitasi peserta didik untuk mencapai hasil belajar yang optimal.

Dengan demikian maka strategi dapat diartikan sebagai perencanaan yang dirancang secara menyeluruh yang mencakup pendekatan metode materi media dan sarana pendukung lain untuk memberikan pengalaman belajar ke pusat kepada peserta didik.

Pemakaian suatu strategi pembelajaran dalam kelas harus memperhatikan berbagai pertimbangan antara lain tujuan yang akan dicapai bahan atau materi pembelajaran peserta didik serta kesiapan buku dengan pertimbangan hal-hal tersebut diharapkan strategi pembelajaran yang diputuskan akan dipakai sebisa mencapai keberhasilan yang optimal. Sementara itu pembelajaran aktif atau aktif learning merupakan segala bentuk pembelajaran yang memungkinkan siswa berperan secara aktif dalam proses pembelajaran itu sendiri baik dalam bentuk interaksi sesama siswa maupun siswa dengan pengajar dalam proses pembelajaran tersebut.

Menurut Zaini (2008), pembelajaran aktif atau aktif learning adalah pembelajaran yang mengajar beserta didik untuk belajar secara aktif belajar aktif di sini menekankan bahwa siswa harus mendominasi aktivitas pembelajaran di kelas siswa diajak turut serta dalam menentukan materi memecahkan berbagai persoalan dan mengaplikasikan pengetahuan yang didapat nya dalam kehidupan sehari-hari dengan kata lain siswa dikatakan belajar secara aktif ketika mereka secara terus-menerus terlibat lebih banyak energi mental dan emosional serta mengaktifkan kelima panca indera secara penuh sehingga pembelajaran seperti ini membuat mereka merasa menjadi bagian dalam proses pembelajaran. Strategi pembelajaran aktif adalah perencanaan menyeluruh meliputi seluruh perangkat pembelajaran untuk membuat pengalaman belajar siswa secara aktif.

Strategi pembelajaran aktif pada dasarnya merupakan suatu cara yang digunakan guru dalam upaya memperdalam proses belajar mengajar untuk mengupayakan siswa agar yang awalnya belum aktif menjadi lebih aktif dalam proses pembelajaran di kelas.

Ada beberapa permasalahan yang dihadapi oleh siswa dalam proses pembelajaran. Oleh karena itu, salah satu cara untuk mengatasi permasalahan tersebut yaitu dengan cara guru menerapkan strategi pembelajaran agar siswa lebih aktif dan mampu meningkatkan pemahaman tentang apa yang telah dipelajari. Salah satu strategi pembelajaran aktif yang dapat digunakan untuk meningkatkan kualitas hasil belajar siswa adalah strategi pembelajaran aktif tipe crossword puzzle (teka-teki silang).

Beberapa alasan yang dapat mendasari perlunya menerapkan strategi pembelajaran aktif tipe crossword puzzle karena dalam pelaksanaannya, siswa diajak untuk meninjau kembali materi yang telah diajarkan dengan bentuk crossword puzzle sehingga mendukung daya ingat siswa dalam materi yang telah diajarkan yang nantinya akan berpengaruh terhadap hasil belajar yang diinginkan. Strategi pembelajaran aktif tipe crossword puzzle dapat membuat siswa menjadi berminat dan berpartisipasi dalam pembelajaran tanpa kehilangan esensi belajar yang sedang berlangsung.

Menurut Dewi (2017) crossword puzzle adalah strategi yang dikembangkan dan diklasifikasikan oleh Mel Silberman pada (active learning) bagian keempat "Bagaimana agar belajar tidak lupa". Crossword puzzle digunakan untuk membantu siswa mengingat dan meninjau kembali materi dan konsep yang telah didapat sebelumnya. Penggunaan strategi permainan di dalam kelas tampaknya dapat menjadi pilihan yang efektif, terutama bagi siswa sekolah dasar. Tidak hanya dapat mengakomodasi berbagai gaya belajar, permainan juga meminimalkan pengulangan dan kebosanan 
di kelas.

Selain itu diperkuat oleh pandangan Jaramillo (2012) " ... that students perceive the use of cross-word puzzles as a fun way to learn specific material in a course". Pandangan tersebut diartikan bahwasannya banyak siswa yang menyadari menggunakan teka-teki silang sebagai cara yang menyenangkan belajar materi spesifik dengan tepat pandangan tersebut berimplikasi bahwa crossword puzzle dapat mengurangi ancaman suatu pelajaran dan membuat siswa merasa nyaman belajar dikarenakan siswa berperan aktif dalam membuat keputusan dan pemecahan masalah sendiri sehingga dapat memperkuat rasa percaya diri dan meningkatkan kemampuan berpikirnya.

Crossword puzzle (teka-teki silang) adalah suatu strategi yang mampu memacu keaktifan dan partisipasi siswa. Seperti yang dijelaskan oleh Faisal dalam Zaini (2008: 71), dalam bukunya strategi pembelajaran aktif bahwa:

Crossword puzzle atau teka-teki silang adalah sebuah teka-teki kata dalam kotak hitam dan putih yang berbentuk persegi yang tujuannya untuk menulis satu huruf disetiap persegi putih untuk membuat kata-kata dengan diberikan petunjuk pertanyaan. Crossword puzzle juga merupakan salah satu metode pembelajaran aktif bagi peserta didlk yang melibatkan semua peserta didik untuk berfikir saat pembelajaran berlangsung dengan mengisi teka-teki silang (crossword puzzle) sehingga peserta didik lebih antuasias dalam mengikuti pelajaran.

Crossword puzzle (teka-teki silang) dapat digunakan sebagai strategi pembelajaran yang baik dan menyenangkan tanpa kehilangan esensi belajar yang sedang berlangsung. Bahkan strategi ini dapat melibatkan partisipasi peserta didik secara aktif sejak awal.

Indriawati (2011:11) menyatakan bahwa strategi pembelajaran crossword puzzle merupakan strategi pembelajaran yang memadukan kegiatan belajar dan bermain. Dalam pembelajaran yang menggunakan strategi ini siswa tidak hanya bermain teka-teki silang tapi juga belajar tentang suatu materi melalui teka-teki silang. Sehingga siswa lebih antusias serta tertarik dalam mengikuti pembelajaran.

Pembelajaran crossword puzzle ini sangat cocok diterapkan pada materi yang bersifat teori yang berbentuk pengenalan suatu alat maupun nama-nama asing karena dalam pembelajaran ini peserta didik dilatih untuk mengingat, memahami serta mencocokan kata sesuai nama dan fungsi alat tersebut, sebagaimana yang dikemukakan oleh Radili (2011:63) yaitu pada dasarnya, teka-teki silang merupakan kegiatan mengingat, mencari dan mencocokan kata yang pas tidak hanya sesuai dengan jawabannya, tetapi juga jumlah kotak yang disediakan.

Menurut Amirul (2016) fungsi kegunaan dari teka-teki silang itu sendiri yaitu membangun sarafsaraf otak yang memberi efek menyegarkan ingatan sehingga fungsi kerja otak kembali optimal karena otak dibiasakan untuk terus menerus belajar dengan santai. Karena belajar dengan santai inilah yang dapat membuat siswa lebih paham dan mudah masuk dalam ingatan siswa sehingga siswa tidak mudah lupa dengan materi yang sudah diajarkan.

Langkah-langkah yang harus dilakukan untuk dapat melaksanakan metode pembelajaran crossword puzzle adalah sebagai berikut : tulislah kata-kata kunci, terminologi atau nama-nama yang berhubungan dengan materi yangtelah anda berikan, buatlah kisi-kisi yang dapat diisi dengan katakata yang telah dipilih (seperti dalam teka-teki silang). Hitamkan bagian yang tidak diperlukan, buat pertanyaan-pertanyaan yang jawabannya adalah kata-kata yang telah dibuat atau dapat juga hanya membuat pernyataan-pernyataan mengarah kepada kata-kata tersebut. Bagikan teka-teki ini kepada peserta didik. Bisa individu atau kelompok, batasi waktu pengerjaan beri hadiah kepada kelompok atau individu yang mengerjakan paling cepat dan benar. Mursilah dalam Zaini (2008:71).

Manfaat crossword puzzle antara lain teka-teki sebagai pengasah daya ingat yang telah didapatkan oleh seorang anak, peserta didik mendapatkan kesempatan untuk beradu pengetahuan dengan lawan lainnya, dapat mengembangkan kemampuan analisa peserta didik, dapat menghibur peserta didik dan teka-teki silang dapat membantu peserta didik dalam menyalurkan potensi-potensi kreativitas yang dimilikinya.

Karakteristik strategi pembelajaran aktif tipe crossword puzzle menurut Kurniawati dalam 
Istifaiyah (2010:26-27) yaitu permainan bahasa yang terdapat unsur kegembiraan dan melatih keterampilan berpikir dan menebak kata-kata yang terdapat pada pernyataan yang diberikan. Pernyataan bersifat menurun dan mendatar serta pernyataan dapat berupa definisi istilah, lawan kata (antonim), persamaan kata (sinonim), dan sebagainya. Pengisian crossword puzzle harus menyelaraskan isian dari pernyataan menurun dan mendatar sehingga membentuk kata-kata yang saling berhubungan satu sama yang lain.

Menurut Davis, dkk.telah menjelaskan secara rinci kelebihan maupun kekurangan strategi crossword puzzle. Kelebihan crossword puzzle dapat fleksibel dalam pembelajaran apapun, crossword puzzle dapat menjadi alat pembelajaran yang efektif untuk mempelajari terminologi, definisi ,pengerjaan, dan kata kunci yang berkaitan dengan nama dan fakta, crossword puzzle membantu siswa memahami area yang telah dimengerti dan area yang belum dipahami nya. Saat siswa dapat menjawab benar mereka akan terus merasa percaya diri dan semakin ingin meningkatkan kinerja nya. Sedangkan saat mereka menemukan kesulitan mereka akan mudah bertanya dan mencari tahu jawaban benar. Sehingga memudahkan guru membedakan konten yang sulit maupun mudah.

Selain itu, crossword puzzle meningkatkan motivasi dan ketertarikan siswa terhadap suatu topik. Ketika siswa mampu menjawab benar suatu pertanyaan, mereka akan memiliki kepuasan tersendiri yang terbukti akan memperkuat keinginannya untuk terus belajar. Kemudian crossword puzzle dapat menjadi aktivitas rekreasi. Strategi pembelajaran ini dapat membuat siswa merasa nyaman dan mengurangi tekanan dalam pembelajaran dibanding teknik pembelajaran tradisional.

Adapun kelemahan dari strategi pembelajaran aktif tipe crossword puzzle yang pertama banyak siswa yang mengartikan teka-teki silang sebagai rekreasi semata sehingga banyak yang tidak serius mengerjakannya. Diantaranya beranggapan bahwa crossword Puzzle tidak penting. Kemudian menitikberatkan pada konsep dalam arti crossword puzzle hanya dapat digunakan untuk mengukur keberhasilan belajar siswa pada konsep yang sifatnya hafalan prosedur pembuatan crossword puzzle saja hanya menitikberatkan untuk mencari kata kunci atau keyword dari konsep yang dipelajarinya. Jadi crossword puzzle sulit diaplikasikan untuk konsep yang banyak membutuhkan analisis.

\section{PENUTUP}

Hasil analisis data dan pembahasan penelitian, dapat disimpulkan bahwa terdapat pengaruh yang signifikan pada penerapan strategi pembelajaran aktif tipe crossword puzzle terhadap hasil belajar. Dari hasil penelitian yang bersumber dari artikel lain yang telah dikaji peneliti bahwa dengan menggunakan strategi pembelajaran aktif tipe crossword puzzle ini pada mata pelajaran Pendidikan Kewarganegaraan, hasil belajar siswa mengalami peningkatan. Dapat disimpulkan terdapat perbedaan hasil belajar peserta didik pada mata pelajaran Pendidikan Kewarganegaraan sebelum dan setelah penggunaan strategi pembelajaran aktif tipe crossword puzzle.

Hasil penelitian juga menunjukkan bahwa nilai hasil belajar dan keaktifan peserta didik mengalami peningkatan. Jadi dapat disimpulkan bahwa penggunaan strategi pembelajaran aktif tipe crossword puzzle ini berhasil meningkatkan hasil belajar peserta didik dalam berbagai aspek yakni aspek afektif, aspek kognitif, dan aspek psikomotorik peserta didik. Hal ini menandakan secara umum siswa merasa terdapat pengaruh penerapan strategi pembelajaran aktif tipe crossword puzzle dan dapat membantu siswa dalam memahami materi yang dipelajari serta adanya peningkatan kualitas hasil belajar yang dirasakan oleh pribadi setiap siswa.

Berdasarkan hasil penelitian yang telah dilakukan peneliti dalam penelitian peningkatan kualitas hasil belajar Pkn di sekolah dasar dengan menggunakan strategi pembelajaran aktif tipe crossword puzzle, maka ada beberapa saran yang dapat dikemukakan oleh peneliti, antara lain: bagi siswa strategi pembelajaran aktif tipe crossword puzzle dapat diterapkan untuk dapat menarik siswa dan 
partisipasi siswa dalam pembelajaran $\mathrm{PKn}$, bagi guru strategi pembelajaran aktif tipe crossword puzzle dapat dipakai sebagai alternatif untuk memberikan variasi dalam proses pembelajaran, bagi sekolah yang menerapkan strategi pembelajaran aktif tipe crossword puzzle sebagai bahan masukan dalam upaya meningkatkan kualitas pendidikan dan inovasi strategi pembelajaran aktif yang tepat khususnya dalam meningkatkan hasil belajar PKn, dan bagi peneliti yang ingin menggunakan strategi pembelajaran aktif tipe crossword puzzle dapat ditindaklanjuti pada penelitian berikutnya dengan memperhatikan alokasi waktu, fasilitas pendukung termasuk media pembelajaran, dan karakteristik siswa yang ada pada sekolah.

\section{UCAPAN TERIMAKASIH}

Ucapan terimakasih ditujukan kepada Universitas Islam Negeri Sunan Gunung Djati Bandung dan bapak Dr. Heri Hidayat, S.Sn, M.Pdi serta ibu Heni Mulyani, M.Pd sebagai penyandang dana, atau yang telah memberikan kontribusi kepada peneliti dalam proses penelitian ini. 


\section{DAFTAR PUSTAKA}

Aisyah, S. (2014). Pengembangan Model Pembelajaran Cooperative Learning Match Mata Pelajaran Pendidikan Kewarganegaraan Kelas VII Sekolah Menengah Pertama di Bandar Lampung . Jurnal Unla Bandar Lampung, nd.

Amirul. (2016). Model Pembelaaran Crossword Puzzle Teka-Teki Silang dalam http://fatkhan.web.id/model-pembelajaran-crossword-puzzle-teka-teki-silang/.

Aniza, N. (2018). Hasil Belajar Peserta Didik Kelas V Sekolah Dasar Menggunakan Teka-Teki Silang. jurnal inovasi sekolah dasar, nd.

Cahyo. (2011). Gudang Permainan Kreatif Khusus Asah Otak Kiri Anak. Jogjakarta: Flashbooks.

Davis,dkk, Reviewing for Exams: Do Crossword Puzzles Help in the Success of Student Learning The Journal Of Effective Teaching, Vol.9,No.3,2009).

Dewi, M. N. (2017). Penerapan Strategi Pembelajaran Aktif Crossword Puzzle Untuk Meningkatkan.

Emil, F. (2008). Pengaruh Penerapan Strategi Pembelajaran Crossword Puzzle Pada Pelajaran PKn Terhada Keatifan Belajar Siswa di Kelas VIII MTS Nurul Hilal Senuro Kecamatan Tanjung Batu . Jurnal Unsri, nd.

Indriawati. (2011). Peningkatan Hasil Belajar IPA Melalui Strategi Pembelajaran Crossword Puzzle Pada Siswa Kelas IV SDN 1 Sawahan Juwirig Klaten. Universitas Muhammadiyah Surakarta, nd.

Istifaiyah. (2010). Startegi Pembelajaran Teka-Teki Silang. Jurnal UIN sby, nd.

Jaramillo. (2012). Designing and Solving Crossword Puzzle. Development in Bussines Simulation and Experiential Learning Journal, 39.

Kasmadi dan Sunariah. (2014). Panduan Modern Penelitian Kuantitatif . Bandung: Alfabeta.

Kumalasari, (2018). Peningkatan hasil belajar PKN melalui strategi pembelajaran aktif tipe crossword puzzle. jurnal pendidikan, 71-78.

Marno, S. T. (2008). Manajemen dan Kepemimpinan Pendidikan Islam. Bandung: PT Prefika Aditama.

Mulyasa, E. (2005). Menjadi Guru Profesional. Bandung: PT Remaja Rosda Karya.

Mursilah. (nd). Penerapan Metode Pembelajaran Crossword Puzzle dalam Meningkatkan Hasil Belajar IPS Kelas XII SMK Nurul Huda Sukaraja. Jurnal IImiah Pendidikan dan Ekonomi, 37-47.

Nurani, S. (2008). Pendidikan Berprespektif Globalisasi . Jogjakarta : Ar-Ruz Media.

Pranata Danil. (nd). Penerapan strategi pembelajaran crossword puzzle dalam meningkatkan hasil belajar sejarah kebudayaan islam peserta didik kelas V MI Al-Muhajirin Bandar Lampung. universitas islam negeri raden intan lampung.

Sudjana. (2001). Metode dan Teknik Pembelajaran Partisipatif. Bandung: Falah Production.

Heri Hidayat ${ }^{1}$, Heny Mulyani ${ }^{2}$, Kiki Karlina ${ }^{3}$, Luthika Tsalitsa Faqih ${ }^{4}$, Nitia Andi Narini ${ }^{5}$ 
Sudjana. (2004). Dasar-dasar Proses Belajar Mengajar. Bandung: Sinar Baru Algensido Offset.

Susanto, A. (2013). Teori Belajar dan Pembelajaran di Sekolah Dasar. Jakarta: Kencana Prenada Media Group.

Soyomukti, N. (2008). Pendidikan Berperspektif Globalisasi . Jogjakarta: Ar-Ruz Media.

Winataputra. (1999). Perkembangan Pendidikan Kewarganegaraan Sebagai Wahana Pendidikan Demokrasi di Indonesia . Bandung: CICED .

Zainul, A. (2012). Pendidikan Karakter Berbasis Nilai dan Etika di Sekolah. Jogjakarta: Ar-Ruz Media.

Zaini, H. (2008). Strategi Pembelajaran Aktif . Jogjakarta: Insan Mandiri.

Zaki. (2016). Faktor yang Mempengaruhi Minat BelajarSiswa Kelas I SDN 7 Kute Panang . Jurnal Tunas Bangsa, nd.

Zaini, H. (2008). Strategi Pembelajaran Aktif . Jogjakarta: Insan Mandiri. 